\title{
The Taxing Postseason: The Potential Impact of Unrelated Business Income Taxation on College Football Bowl Organizers
}

\author{
Dylan Williams and Chad Seifried \\ Louisiana State University
}

\begin{abstract}
College football bowl game associations and their organizers hold a distinct advantage over many for-profit sport and entertainment organizations as they are generally exempt from paying any income tax on profits made from their activities each year. However, recent behaviors from bowl game committees have begun to blur the lines between a for-profit company and a nonprofit organization that provides educational or charitable benefits. Specifically, critics have argued bowl associations should be taxed using the Unrelated Business Income Tax (UBIT), which examines if certain business activities are related to the purpose of an exempt organization or more in-line with a for-profit company. With this concept in mind, this review looks to see if some of the latest business ventures and activities implemented and practiced by bowl committees and their partners are protected or subject to the UBIT.
\end{abstract}

During the 2011-2012 football season, 35 bowl contests were created to host 70 of the 120 full members that compete in the National Collegiate Athletic Association's (NCAA) Division I Football Bowl Subdivision (FBS; "College Bowls 2011-12," 2012). According to bylaws 17.9.5 and 18.7.1 provided within the NCAA Postseason Football Handbook (2011), bowl games are postseason contests created to reward those institutions that completed a successful regular season in the Division I FBS. The most prominent postseason events for the Division I FBS are the five games organized by the Bowl Championship Series (BCS). Generating nearly \$771 million between the 2006-07 and 2010-11 fiscal years, the BCS includes the a) Allstate Sugar Bowl, b) Discover Orange Bowl, c) Tostitos Fiesta Bowl, d) Rose Bowl presented by Vizio, and e) BCS National Championship game (NCAA Postseason Football Finances, 2011). Through the respective alliances established between bowl game organizers, television networks (e.g., ESPN, ABC, and FOX), and the FBS institutions, the BCS and other bowl games were formed to produce a national championship contest and other interesting match-ups for consumers (BCS Media Guide, 2011). The NCAA's only interaction with the Division I FBS postseason bowl games is to certify or license their activity [National Collegiate Athletic 
Association (NCAA), 2011]. The other three football championship postseasons (i.e., Division I-FCS, II, and III) and 22 other sports exclusively managed by the NCAA primarily use a playoff format to decide a national champion (NCAA, 2010).

The uniqueness and notoriety of FBS bowl games has corresponded with high consumer interest and prompted bowl game organizers to explore the possibility of further economic gains by incorporating new elements into their annual planning efforts and agreements (Zimbalist, 2009). As an example, the commissioners of the BCS as well as Notre Dame Athletic Director Jack Swarbrick have agreed to begin a four-team seeded playoff system (i.e., College Football Playoff) that would begin after the 2014 regular season (Russo, 2013). Within this arrangement, the Orange, Rose, and Sugar Bowls are already committed to the six-bowl semifinal rotation plan under the marketing direction of Premier Sports Management of Overland Park, Kansas (Russo, 2013). Other recent commercial-oriented actions also include the pursuit of additional corporate sponsorships outside of a title sponsor and the implementation of potentially questionable activities (e.g., excessive corporate perks, inflated executive salaries, political lobbying, and unnecessary game development initiatives) which may contradict the organizational mission or purpose for their nonprofit status (Wight, 2012).

For tax purposes, all Division I FBS bowl committee organizations are classified as a charitable or a nonprofit organization. The Internal Revenue Code's (IRC) Section (\$) 501(c)(3) (2006a) describes a charitable/nonprofit organization as exempt from paying federal income taxes generated within a given fiscal year. Sansing (2001) noted some companies create products with characteristics that promote the exempt organization's core purpose. As an example, the National Geographic Society, which would include the National Geographic Magazine, the firm's film library, and their many trademarks, is classified as such a charitable organization. Thus, when the National Geographic Society or one of its subsidiaries produces videos for a commercial television network, profits made from the sale would not be subject to taxation.

While the $\$ 501(\mathrm{c})(3)$ classification has created a unique situation for nonprofit organizations, its popularity and use has caused concern for some for-profit companies who cannot obtain tax exempt status. In essence, nonprofit firms could have an unfair competitive advantage over their profit-oriented peers within the same business. To rectify the potential misuse and abuse of this advantage, the United States Congress created a tax to manage nonprofit organizations from participating in activities that remove themselves from their core business. Known as the Unrelated Business Income Tax (UBIT), nonprofit companies as defined under $\$ 501(\mathrm{c})(3)$ pay income taxes on all activities that are regularly performed but are drastically different from the main purpose of the nonprofit mission. The United Way, a long-time partner of the National Football League, files a Form 990-T each year to report unrelated business income. For instance, in 2008, their unrelated business income was $\$ 26,250$ and required a payment of $\$ 2,718$ to the U.S. government (Department of the Treasury, 2008).

With the unrelated business tax in mind, many of the recent activities emerging from bowl game committees appear to violate their nonprofit status and thus a review of these practices are necessary to see, not only if the UBIT is applicable but if a potential forfeiture of the $\$ 501(\mathrm{c})(3)$ status in general should be required. Again, such an analysis appears justified since bowl game activities are supposed 
to correspond with specific charitable or educational components. By abandoning these principles in exchange for valuable profit-seeking initiatives which primarily serve to benefit the production of sport products and their executive personnel, a potential suspension of the $§ 501(\mathrm{c})(3)$ tax exemption should emerge.

Interestingly, the UBIT and intercollegiate athletic activities have been analyzed in various tax journals (e.g., Appleby, 2010; Colombo, 2010; Kaplan, 1980) but work is limited in sport-oriented journals. Recently, Williams and Seifried (2013) reviewed the implications of the UBIT on Division I athletic activities and recommended future research could analyze the prospects of the UBIT on other areas of intercollegiate athletics. Appropriately, the goal of this study aims to explain the evolution of the UBIT and review questionable behavior practiced by college football bowl organizations to see if there is any potential tax implications. Specifically, this review will describe the history of the UBIT since its inception and analyze the current business activities of the college bowl game committees that organize the five major games of the BCS, as representative of the bowl system, to identify any departures from their core mission. Finally, both the IRS and the courts reviewed bowl organizations in the past [i.e., Technical Advice Memorandum (TAM) 91-47-007] and have diverse opinions on some elements (Vari, 1992). However, these differences in opinion occurred well before the creation of the BCS in 1998 and the noted expansion regarding the opulence of bowl game operations explained below.

\section{Unrelated Business Income Tax (UBIT) Development}

IRC $\S 1$ and $\S 11$ established that the income of all individuals and all corporations shall be subject to taxation unless an entity qualifies for a specific statutory exemption (Smith, 2010). One specific exception to this general rule is found in $\$ 501$ (c) (3) which states any organization

"organized and operated exclusively for religious, charitable, scientific, test-
ing for public safety, literary, or educational purposes, or to foster national or
international amateur sports competition (but only if no part of its activities
involve the provision of athletic facilities or equipment), . . . no part of the net
earnings of which inures to the benefit of any private shareholder or individual,
no substantial part of the activities of which is carrying on propaganda, or oth-
erwise attempting, to influence legislation ..., and which does not participate
in, or intervene in (including the publishing or distributing of statements), any
political campaign on behalf of (or in opposition to) any candidate for public
office" can secure status as tax exempt. (IRS, 2006a, para. 6)

Collectively, the $\$ 501(\mathrm{c})(3)$ exemption's main purpose is to provide a favorable treatment to those organizations that foster activities which serve the greater good to others in society (Craig \& Weisman, 1994; Smith, 2010).

Before 1950, $\$ 501(\mathrm{c})(3)$ organizations enjoyed the benefits of their status as a form of competitive advantage over for-profit enterprises. Specifically, tax-exempt organizations paid no taxes on profits for activities that were either related or unrelated to their tax exempt purpose (Sansing, 2001). Thus, universities and colleges throughout the 1930s and 1940s increasingly operated a variety of commercial 
enterprises that directly competed with for-profit entities (Kaplan, 1980). This behavior was initially supported by the Trinidad $v$. Sagreda Orden de Predicadores (1924) decision which allowed activities unrelated to institution's core mission to be tax exempt as long as the activity's income was connected to a charitable or educational organization. Expectedly, many charitable and educational institutions increased their entrepreneurial activities under the protection of $§ 501$ (c)(3) but the loss of potential U.S. tax revenue eventually prompted the alteration of the tax code and the development of the UBIT.

One of the most public cases dealt with New York University's (NYU) ownership of the C.F. Mueller Macaroni Company (Kaplan, 1980). Specifically, Congress feared products created by university-owned business would limit the amount of revenue the Federal Treasury received from a particular industry each given year (Kaplan, 1980; Smith, 2010). With added support from President Harry S. Truman, Congress eventually established the Unrelated Business Income Tax as a tax that can be levied on all $\$ 501(\mathrm{c})(3)$ organizations participating in activities unrelated to the organization's mission (IRS, 1960a; Kaplan, 1980). Further, Truman and Congress suggested the UBIT was created to protect 1) the Department of the Treasury from future losses of revenue and 2) taxpaying entities from unfair competition (Smith, 2010).

\section{UBIT Rules and Exceptions}

IRC \$512(a)(1) defines unrelated business taxable income as "gross income derived from any unrelated trade or business regularly carried on, less those deductions allowed ... . which are directly connected with the carrying on of such trade or business" (IRS, 2000, para. 2). The UBIT taxes on income generated from unrelated business activities of $\$ 501(\mathrm{c})(3)$ organizations occurs at rates applicable to taxable corporations (Appleby, 2010). To determine if a $\$ 501(\mathrm{c})(3)$ organization has unrelated business income, a three-prong test is used to analyze if an activity is considered unrelated. This differs from the original destination test created by the Trindad case as Congress wanted to review the source of the income as opposed to its destination.

For a $\$ 501(c)(3)$ organization to be subject to the UBIT, it must first engage or participate in a trade or business (Appleby, 2010; Colombo, 2010; Smith, 2010). According to $\$ 513(\mathrm{c})$, a trade or business is defined as "any activity which is carried on for the production of income from the sale of goods or the performance of services" (IRS, 2006b, para. 1). Despite this point, the IRS does not consider every activity in which a business partakes for profit generation as a trade or business. Thus, the IRS must conduct a fact-specific inquiry to determine whether an activity is actually a trade or business (Smith, 2010). As an example, all students attending a particular university will pay tuition to enroll in class. Within, the IRS would recognize the university does not necessarily have a profit interest when collecting tuition because that money is generally recognized as being used for faculty and staff salaries, maintenance of university buildings, research support, and student activities. In contrast, if a university decided to open a commercial activity such as an airport or a hardware store off campus, this would constitute an active participation in an activity that deviates from the core purpose of the university. 
It should be noted that some trades or businesses performed for the convenience of organizational stakeholders are not subject to the UBIT (Kaplan, 1980). For instance, the Member/Student Exception allows colleges and universities to provide services for the convenience of students and faculty (Kaplan, 1980). Take for example, an on-campus bookstore that sells books and other materials for students and faculty. The bookstore is a separate entity from the university but due to its association, the bookstore will not have to pay taxes on profits generated from sales. Finally, IRC §513(a)(1) (2010) notes the UBIT will not be applied to a trade or business if a substantial amount of work can be performed for an organization without providing compensation for services. For instance, Pena and Reid (2001) highlighted income generated from the operation of bingo games and other work within charitable organizations is not subject to the UBIT if a substantial amount of work was carried out by unpaid volunteers.

The second of the three-prong test requirement states that an organization must conduct a trade or business on a regular basis. To determine this, the IRS and Treasury Regulations require a consideration for frequency and continuity with the activities conducted and the manner in which they are pursued (Plunkett \& Christianson, 2004). Specifically, the IRS reviews the frequency and continuity of certain activities through comparing if they are conducted in a similar manner to profit-generating organizations (Smith, 2010). Thus, if an exempt organization's activities are carried on generally and similar to comparable commercial activities of for-profit businesses, the IRS will deem these procedures as regularly carried on activities and a potential trigger to the UBIT. Importantly, Treasury Regulation \$1.513-1(c)(2)(i) (1983) proscribes seasonal activities can be considered to be regularly carried on if they are conducted during a significant portion of the year. However, activities lasting only a short period of time, such as fundraisers, will not ordinarily be treated as regularly carried on if they occur on an irregular basis (i.e., occasionally or sporadically) (Plunkett \& Christianson, 2004; Smith, 2010).

The final and third critical factor has been subject to much interpretation and debate since the inception of the UBIT. Specifically, this consideration requires a nonprofit entity to pay the UBIT if it is regularly conducting business that is substantially unrelated to the purpose of the exempt organization (Plunkett \& Christianson, 2004). Jensen (1987) stated a substantial relationship or justification can only exist if the activity in question contributes importantly to the accomplishment of the organization's exempt purpose. Thus, the IRS has the authority to decide, on a case-by-case basis, whether specific or combinations of activities performed by organizations are substantially related or not (Craig \& Weisman, 1994; Plunkett \& Christianson, 2004). Their authority considers size and extent of activities in relation to the nature and extent of the exempt function they purport to serve.

An additional exception to consider under the UBIT is the IRS's fragmentation rule (Colombo, 2010). Here IRC \$513(c) (2006b) provides the IRS the ability to separate particular revenue streams from an organization if they are substantially unrelated to the organization's mission. In the past, the courts have approved of this in its ruling for the case The United States v. American College of Physicians (1986). Specifically, this case reviewed all income generated from medical product advertisements in one of the American College of Physicians' (ACP) medical jour- 
nals. In its decision, the court found the ACP's reason for advertisement solicitation did not contribute to the educational value of the journal and the UBIT was used only on their advertising sales. Further, the court suggested if the ACP coordinated their advertisements with the purpose of the magazine, the UBIT would not have been imposed (Vari, 1992).

Finally, although Congress altered their test of design to implement taxes on nonprofit companies, some specific exceptions on certain activity elements are allowed. For example, IRC §511(b) states income from passive investments, such as dividends, interest, rents, and royalties, are exempt from UBIT (IRS, 1960b). However, this exemption could lead to abuse if $\$ 501(\mathrm{c})(3)$ organizations could operate unrelated commercial enterprises through a taxable subsidiary (Sansing, 2001; Smith, 2010). As an example, an exempt organization can retain the assets of the subsidiary and receive rent or royalty payments. The subsidiaries, which were subject to income taxes, would issue annual payments to their parent company and deduct the total amount of payments as an expense. The parent tax-exempt organization then would not have to pay UBIT since they received passive income from the subsidiary in the form of rent or royalty payments (Sansing, 2001). Within these rules and exceptions, we now review current and past behaviors exhibited from bowl game committees to determine if any UBIT uncertainties are real.

\section{Bowl Game Committees and Organizational Activities}

As noted previously, the NCAA does not own or operate any postseason contest for the Division I FBS. Bowl games are generally organized and controlled by local chambers of commerce, convention and tourist bureaus, and assorted businesses in cooperation with the aforementioned corporate sponsors, television networks, and FBS institutions (Seifried \& King, 2012; Zimbalist, 2009). The original and well established purpose of bowl games was to generate business for the local economy through tourism prompted by the college postseason and annual holiday season festivals created within host communities (Seifried \& King, 2012). To help expand interest, these host organizations and communities created horizontal agreements with the member institutions and conferences to organize the postseason contests. ${ }^{1}$ Participating schools, in return, enjoyed a share of the bowl revenue which it attempted to help secure by selling tickets to alumni, students, boosters, and others (Seifried \& King, 2012; Zimbalist, 2009).

Since bowl organizers operate independently from the NCAA, bowl committees can prepare procedures and engage in activities which serve to increase their profit potential as well as for those of their partners. While some of these activities are necessary to increase the exposure of intercollegiate sports and charitable causes also associated with bowl games, several bowl organizations have begun to blur the lines between the purpose of a for-profit company and that which justifies a tax-exemption as an educational or charitable institution through some controversial activities. The following are publicized examples from the four largest bowl organizers (i.e., BCS games) within the last five years which could trigger the UBIT. 


\section{Inflated Salaries}

If $\$ 501(\mathrm{c})(3)$ organizations wish to maintain their tax-exempt status, certain guidelines must be followed. For instance, $\$ 501(c)(3)$ organizations cannot use any part of net earnings to inure to the benefit of any private shareholder or institution (Colombo, 2010; IRS, 2006a). Despite various interpretations throughout the years, the IRS defines private inurement as the siphoning off of the assets of an exempt organization to an insider or a small number of employees (Hill \& Mancino, 2009). Typically, private inurement involves $\$ 501(\mathrm{c})(3)$ organizations paying above-market prices for either property owned or services provided by an individual. A classic example of this practice is to pay an illogical salary to any one individual in excess of what the services are worth (Colombo, 2010).

Compensation for officials of the Fiesta, Orange, Rose, and Sugar Bowls have more than doubled since the formation of the BCS in the 1998-99 season and their average compensation now exceeds $\$ 500,000$ (Harris, 2011). As an example, Form 990 from the Arizona Sports Foundation (ASF) return showed former Executive Director of the Fiesta Bowl, John Junker, made \$673,888 for the 2010 fiscal year working an average of $21 \mathrm{hr}$ per week (Department of the Treasury, 2010a). This is a sharp increase from the 1998-1999 season when Junker made \$200,000. Interestingly, the 2009 ASF tax return also showed another bowl executive, Chief Operating Officer (COO) Natalie Wisneski, earning \$391,824 during that fiscal year.

Sugar Bowl Committee CEO Paul Hoolahan also earned \$593,718 for his work in 2010 fiscal year (Department of the Treasury, 2010b). Like Junker, Hoolahan earned significantly less (i.e., \$160,500, a 270\% increase) in 1998-1999 when the BCS era began (Harris, 2011). In recent years, Orange Bowl executives, such as Chief Financial Officer (CFO) Brian Park and CEO Eric Poms also made $\$ 257,378$ and $\$ 357,722$ respectively (Department of the Treasury, 2010c). Poms, promoted to CEO in 2006, saw his salary rise $\$ 150,000$ from his original position as Orange Bowl COO (Harris, 2011). Finally, the former CEO of the Rose Bowl, John Dorger, made \$277,929 in the 2009 fiscal year (Department of Treasury, 2009). His replacement, P. Scott McKibben, was scheduled to make $\$ 425,000$ in base salary and $\$ 200,000$ in bonuses (Harris, 2011). McKibben, however, opted to resign from his position, citing personal and philosophical differences with the Rose Bowl committee. Had McKibben chosen to remain his pay would have been $374 \%$ higher than his predecessor.

Next, it is also important to recognize the BCS bowl committees are not the only organizations to provide their top executives with high salaries. The culture of high executive salaries is prevalent throughout the bowl system. For instance, Wetzel, Peter, and Passan (2010) found most other non-BCS bowl games also provided their CEOs with compensation packages or executive salaries that rival the BCS bowl committees. As an example, Jim McVay, CEO for the Outback Bowl, earned over $\$ 800,000$, easily outdistancing the highest among bowl executives in the 2009 fiscal year. Table 1 shows in spite of size, the less prestigious bowl organizations are behaving like their BCS peers (McMurphy, 2011).

Based on these examples, the salaries for bowl executives appear to be significantly higher than executives of similarly sized nonprofit organizations. This is important to note due to IRC $\$ 4958$ which highlights compensation is determined to be reasonable only if the reward is similar to the market value for services in both the nonprofit and for-profit sectors (IRS, 1996). According to a survey conducted 
Table 1 Notable Bowl Committee CEO Salaries for 2008-2009 and/or 2009-2010

\begin{tabular}{lll}
\hline Bowl committee & CEO & Salary \\
\hline Outback Bowl & Jim McVay & $\$ 808,032$ \\
Chick-fil-A Bowl & Gary Stokan & $\$ 626,321$ \\
Cotton Bowl & Rick Baker & $\$ 419,873$ \\
Alamo Bowl & Derrick Fox & $\$ 419,045$ \\
Kraft Fight Hunger Bowl & Gary Cavalli & $\$ 377,475$ \\
Gator Bowl & Rick Catlett & $\$ 338,365$ \\
Holiday Bowl/Poinsettia Bowl & Bruce Binkowski & $\$ 261,496$ \\
Capital One Bowl/Champs Bowl & Steve Hogan & $\$ 242,584$ \\
Music City Bowl & Scott Ramsey & $\$ 238,594$ \\
Humanitarian Bowl & Kevin McDonald & $\$ 200,599$ \\
Sun Bowl & Bernie Olivas & $\$ 166,088$ \\
Independence Bowl & Missy Setters & $\$ 110,217$ \\
GoDaddy.com Bowl & Mike Gottfried & $\$ 90,000$ \\
Military Bowl & Stephen Beck & $\$ 37,500$ \\
\hline
\end{tabular}

Note. Salaries of bowl game executives are not reflective of a $40 \mathrm{hr}$ per week job. Retrieved from "Bowls pay bowl officials big bucks," by B. McMurphy. (2011, January 10), San Francisco Gate.

by GuideStar USA, Inc., nonprofit entities with a budget similar to the BCS bowls ( $\$ 10$ million to $\$ 25$ million) paid their executives approximately $\$ 225,239$ (Harris, 2011). Charity Navigator (2010), a company studying CEO salaries, also similarly discovered nonprofit entities with a budget similar to the BCS bowls paid their CEOs approximately $\$ 185,000$ on average with the highest being paid $\$ 383,500$. Notably, the salaries for both Junker and Hoolahan alone are more than double this average and near the highest salaries. Next, if executive salaries (i.e., average $\$ 309,466$ ) of nonprofit firms with budgets ranging as high as $\$ 50$ million are compared with bowl game executives, BCS bowl game executive salaries still remain significant. Further, this information and other records obtained by The Arizona Republic on more than 6,500 nonprofit organizations show BCS executives would be in the top $2 \%$ of compensation of similarly sized nonprofits and in the top $9 \%$ of those with budgets nearly twice their size (Harris, 2011).

\section{Corporate Perks}

Colombo (2010) stated the IRS will apply the UBIT and potentially strip §501(c)(3) organizations of their tax-exempt status should the organization provide excessive benefits to parties outside of the charitable class. These benefits do not necessarily have to be financial in nature but normally take that form. Private benefits differ 
from the private inurement rules as it applies to activities involving independent parties who have minimal association with the $\$ 501$ (c)(3) organization. However, if an activity is considered to be incidental, a $\$ 501(\mathrm{c})(3)$ organization will not be penalized. To be considered incidental, the benefit must be a necessary component of the activity which will benefit the general public at large even though it is for specific private individuals (Colombo, 2010). In addition, the private benefit must not be substantial after considering the overall public benefit.

After reviewing these rules and analyzing past tax returns, it appears the four largest BCS bowl game organizations are also in violation of the private benefit rules at the expense of their charitable, community, or educational partners. As an example, former Fiesta Bowl CEO Junker enjoyed use of organizational money for his own personal benefit. Some of the items charged to the Fiesta Bowl included $\$ 33,000$ for his own Pebble Beach birthday party; $\$ 19,000$ for three country club memberships in different states; $\$ 90,000$ in a charity auction for a round of golf with Jack Nicklaus; and \$1,200 for multiple visits to adult entertainment establishments (Baratz, 2011). In addition to Junker's actions, the Fiesta Bowl provided other top personnel and their spouses first class travel during the 2009 fiscal year which cost \$381,000 (Department of the Treasury, 2010a). This total was slightly above their five-year average of $\$ 304,275$. In comparison with similarly sized nonprofit firms, Charity Navigator (2010) reported none of these institutions provided first class travel for their executives or their spouses.

Orange Bowl executives were also treated to their own first class travel throughout the country totaling over $\$ 750,000$ in the 2009 fiscal year (Department of the Treasury, 2010c). Specifically, a 2010 letter from the IRS to the Orange Bowl Committee showed the Orange Bowl Committee used bowl funds to treat Orange Bowl executives and college athletic directors to a four-day "complimentary getaway" aboard the Royal Caribbean's Majesty of the Seas in July 2010 (Hlas, 2011). Entitled "Summer Splash," the cruise was nothing more than a corporate getaway for all invitees and their spouses. No business meetings were listed or held based on the cruise's agenda ("Guest Manual," 2010). It was the quintessential perk for bowl game organizers, their friends, and Division I FBS athletic department partners.

First class travel was also not the only corporate benefit bowl game executives received over the years. As an example, in addition to Junker, the Fiesta Bowl paid private country club membership dues for other executives to the sum of $\$ 240,000$ (Department of the Treasury, 2010a). Similarly, the Orange Bowl and Sugar Bowl tax returns reported their committee executives received numerous opportunities to enjoy luxury golf outings with their friends. For instance, the Orange Bowl supplied \$42,000 for golf outings in 2010 (Baratz, 2011). Notably, Charity Navigator (2010) observed $12.5 \%$ of similarly sized nonprofit organizations did pay for private club membership but acknowledged this is a common tradeoff for the acceptance of a lower executive salary. Again, the bowl game executives stay ahead of their nonprofit peers.

Other 'gifts' were also featured in several other bowl game tax reports. For example, according to the Orange Bowl Committee, Inc. (Department of the Treasury, 2007), the Orange Bowl spent \$535,764 on "gifts" in the 2006 fiscal year. In addition, \$331,938 was paid for "parties" during the 2004 fiscal year. The Fiesta Bowl tax returns (Department of the Treasury, 2010a) similarly showed outrageous spending of roughly $\$ 1.2$ million on their "Fiesta Frolic," an annual weekend golf 
retreat for college-football officials at a Phoenix-area resort that occurred from 2004-2006. The Sugar Bowl tax return (Department of the Treasury, 2010b) further reported significant activity in a special category entitled "special appropriations." This is 'vague' category produced totals as high as $\$ 750,000$ in multiple fiscal years. Similarly, the Rose Bowl tax return displayed a similarly undefined category entitled "other outside services" worth \$3.4 million (Rose Bowl Operating Company, 2009). Without a proper categorization for these ambiguous line-items on tax returns, the potential for abuse and misuse of bowl revenues is elevated.

\section{Guaranteeing Revenue Through Contractual Obligations}

Another benefit that bowl organizations maintain involves the influence committee members have over institutions. The bowl committees require invited teams to engage in certain business transactions which ultimately guarantee their salaries and executive benefits. One such required transaction demands participating schools to purchase game tickets ranging from 10,000-17,500 per bowl game (Baratz, 2011). The schools can resell these tickets to students, alumni, and other interested fans but often fail to sell them all. For instance, when The Ohio State University played in the 2009 Fiesta Bowl, they failed to sell over 7,000 of their allotted tickets (Baratz, 2011). This cost Ohio State an additional $\$ 1$ million in expenses but not the Fiesta Bowl who received their financial guarantee from Ohio State before the game.

In addition to ticket sales, bowl organizations also arrange the lodging required for both participating teams through self-serving partnerships they created. As an example, the Fiesta Bowl requires schools to purchase 3,750 rooms at a hotel of the committee's choosing for their stay in Arizona at a rate of $\$ 200$ per night (Baratz, 2011). The schools are required to pay for these rooms whether they use them or not. Junker requested this arrangement due to a side deal he made with the Scottsdale Convention and Visitors Bureau. The Bureau agreed to provide the Fiesta Bowl $\$ 8.2$ million over the next 20 years if the committee agreed to funnel their participants to the Scottsdale resorts (Baratz, 2011). Sugar Bowl CEO Paul Hoolahan has an identical arrangement with New Orleans hotels while many other bowl games have been accused of similar extortion-like practices (Baratz, 2011).

\section{Lobbying and Political Contributions}

IRC $\$ 501(c)(3)$ explicitly states "no substantial part of the activities of which is carrying on propaganda, or otherwise (including the publishing or distributing of statements), any political campaign on behalf of (or in opposition to) any candidate for public office" is permitted (IRS, 2006a, para. 6). Thus, the concept of lobbying should not be conducted by $\$ 501(\mathrm{c})(3)$ firms. However, the culture of lobbying and the acceptance of that activity are prevalent with the Division I FBS bowl system (Seifried \& King, 2012). As an example, through lobbying efforts by the committees, desired teams were regularly courted to appear in postseason games to produce a strong economic impact for host locations and larger profits for the bowl game organizers (Seifried \& King, 2012). These invitations were frequently sent out well before the season's conclusion before the establishment of the BCS in 1998 (Seifried \& Smith, 2011). In addition to bowl invitations, there were also lobbying efforts from executives to maintain or increase their status to full-time 
employee compensation even though they completed only part-time work for the bowl organization (Seifried \& Smith, 2011).

Appropriately, it should not come as a surprise that political lobbying occurred when it could potentially serve to reassure the survival of bowl games and, correspondingly, the pay and executive perks enjoyed by their organizers. In December 2009, The Arizona Republic reported such activity through their discovery that staff members of the Fiesta Bowl were asked to make political contributions for specific political candidates and reimbursed for those contributions (Murphy \& McKnight, 2011). Kelly Keogh, an executive assistant with the Fiesta Bowl confirmed this practice was routine for the Fiesta Bowl since 2002 and possibly further before that point (Murphy \& McKnight, 2011). The Chairman of the Board of Directors for the Fiesta Bowl, Duane Woods, created an investigation which led to a 276-page report detailing not only the political contributions and the cover up of these actions, but also several extravagant and inappropriate expenditures by former CEO John Junker (Madel, Manning, \& Poulos, 2011). In addition to the expenditures discussed earlier, other expenditures included a $\$ 75$ bill for flowers sent to the University of Texas at Austin admissions office (Murphy \& McKnight, 2011 ) to $\$ 65,000$ in flights and other travel arrangements for various legislators and their family for the 2008 Fiesta Bowl to help prompt a potential invitation (Madel, Manning, \& Poulos, 2011).

After reviewing these points, it is clear that lobbying activities and the distribution and reimbursement of political campaign donations drastically deviates from the principle meaning of bowl games (Madel, Manning, \& Poulos, 2011). Furthermore, a profit motive is evident through the service of reimbursing committee member and employee paychecks. While bowl committees have evolved from their original beginnings, the practice of lobbying appears to survive and flourish. Moreover, committee members from any bowl could potentially and may have already engaged in similar activity to promote their organizational message for personal executive benefits.

\section{Community Outreach vs. Game Development}

As previously stated, the rationale behind the $\$ 501(\mathrm{c})(3)$ exemption was also to provide favorable treatment to those organizations that foster activities serving the greater good (Craig \& Weisman, 1994). This can be conducted through various means but generally deals with community outreach. In particular, bowl committees suggest they seek to improve their local community by supporting charitable organizations and the quality of resources in poor areas of the region. As an example, the Orange Bowl mission is aimed at improving the local community through economic advancement, higher education support, and youth program development ("Community Development," 2011). However, based on the Orange Bowl tax returns, it does not appear any of those visions are being fully addressed or realized.

The majority of program expenses for the Orange Bowl Committee center on the commercial production of the game itself instead of maximizing charitable contributions. Per the 2010 Orange Bowl tax return, the committee spent roughly $\$ 12.1$ million of its $\$ 13.1$ million in program expenses on the Orange Bowl contest in 2010 (Department of the Treasury, 2010c). The remaining expenses were used 
to support local youth sport leagues $(\$ 625,000)$, provide scholarships to deserving college bound high school students $(\$ 180,000)$, and to renovate a local community park $(\$ 159,000)$. While these are great contributions to the local community, one can infer that the Orange Bowl should spend more on its local community considering the extravagant halftime show it produces, high executive salaries, corporate perks, and the reported $\$ 7$ million in profit earned in the 2009 fiscal year (Department of the Treasury, 2010c).

The Sugar Bowl similarly provides a notable example of preferences for game expenses over that of community redevelopment. According to audited financial statements from the Sugar Bowl (2009), program expenses for the event were $\$ 9.4$ million while support expenses were $\$ 3.8$ million. While support expenses appear to be higher than the support provided by the Orange Bowl, the $\$ 3.8$ million is comprised of $\$ 2.4$ million of general and administrative expenses; $\$ 130,000$ of depreciation expense; and $\$ 85,000$ of miscellaneous expenses. The remaining $\$ 1.15$ million is related to the "special appropriations" account discussed earlier. While this could possibly relate to charitable donations to the community, one can still question the expenses going into the game versus against those of the bowl's recognized mission.

The extravagant halftime shows produced by bowl games are one prime example of potentially misguided expenses. Typically, each college football game in Division I FBS generally has an intermission period in which on site spectators are treated to a musical performance, usually from the home team's musical band. However, with bowl games, much production and hard work goes into preparing the halftime event throughout the year. Thus, the bowl committees go to great length and expense to provide spectators with an extravagant halftime show. Audits of Financial Statements for the Year Ended June 30, 2009 for the Sugar Bowl show the committee paid $\$ 495,302$ for entertainment purposes which included bands from the invited teams (i.e., the University of Utah- The Pride of Utah and the University of Alabama- Million Dollar Band) but other elaborate activities. In the same fiscal year, the Orange Bowl committee also hired two independent contractors, Act Productions, Inc. and Viva Creative, to prepare their halftime show (Department of the Treasury, 2010c). Both companies were paid a combined $\$ 800,000$ for their work on the halftime performance headlined by The Doobie Brothers (Castillo, 2008).

Interestingly, neither the Fiesta Bowl nor the Rose Bowl committees provided dollar figures for their entertainment expenses in terms of halftime performances on their tax returns; however, both provided the amount paid for game expenses. The Rose Bowl committee reported event expenses totaling \$3.9 million in the Basic Financial Statements for the Year Ended June 30, 2009 (Department of Treasury, 2009). While there is no line-item analysis of this figure, the event's expenses involved activities related to the Tournament of Roses and the annual Rose Bowl game halftime show. The Fiesta Bowl reported game expenses in excess of $\$ 9$ million. Again, like the others, this figure includes an elaborate halftime show with bands and props to entertain or to produce a commercial product. While some of these costs are necessary to provide the event and to entertain the spectators, bowl games may pay out exorbitant or excessive rewards for event entertainment which could be better spent toward their core mission. 


\section{UBIT Implications for Bowl Game Organizations}

The review above demonstrates bowl game committees participated in activities that deviated from their educational and charitable missions. However, an evaluation process is necessary to support such claims. Below is the likely evaluation criteria, previously established by Congress, the IRS will use before any decisions can be made about bowl game activities as acceptable or sanction-ready under the UBIT. Again, for the IRS to impose the UBIT on tax-exempt businesses, a nonprofit organization must 1) conduct a trade or business, 2) conduct the trade or business on a regular basis, and 3) have the trade or businesses substantially unrelated to the entity's exempt purpose.

\section{UBIT Rule \#1: Trade or Business}

The Supreme Court (i.e., Jacobellis v. Ohio, 1964) decided an exempt organization is engaged in a trade or business when it provides goods or services to make a profit (Plunkett \& Christianson, 2004; Vari, 1992). Within this perspective, the IRS will first need to consider whether bowl committees act as a supplier to promote itself. The term "supplier" in this work follows the definition established in Utah Code to mean sellor, offeror, or broker "who regularly engages in, or enforces consumer transactions, whether or not he deals directly with the consumer" (Utah Code Ann. 2009, Section 3-6). Bowl game organizations appear to exist as a supplier under the broad interpretation of the definition. In addition, bowl committees also appear to act as the supplier through its offer to sell those contests/games.

As an example, television rights to the games are sold to organizations (e.g., FOX and ESPN) along with opportunities to join the contest as official sponsors/ partner. Merchandise and apparel is also offered for public consumption in association with each respective event. Sweatshirts, logos, hats, and DVDs offered for a fee before and after bowl games serve as excellent examples of this phenomenon. Online methods (e.g., check or credit card) to purchase products and services (i.e., travel) to both consumers and potential clients or partners allow bowl committees to be seen as the broker, sellor, and offeror, and thus, ultimately as the supplier too. Overall, based on this analysis, one can infer that bowl committees do engage in an active trade.

\section{UBIT Rule \#2: Regularly Carried Out Activity}

Next, this work recognizes each committee organizes bowl games once per year. While one could argue bowl games are not a regularly carried out activity, each bowl organization is involved in annual planning which involves a series of activities throughout the year. The IRS previously described advertising, promotion, and scheduling activities as specific products of an active trade or business (Vari, 1992). This decision was in contrast to the NCAA v. Commissioner (1990) in the 10th District court which positioned the rarity of the bowl event as the base for establishing a bowl game as a nonregular activity. The IRS countered by arguing the work involved with the preparation and solicitation of advertising is built to support the relevant time period (Vari, 1992). Thus, for a sponsorship agreement to be classified as a qualified sponsorship activity [i.e., §513(i)(2)(A)], the nonprofit 
entity must only acknowledge the sponsor's name or logo and not advertise the sponsor's products or services (IRS, 1997a). Further, §513(i)(2)(B)(i) requires qualified sponsor agreements not to be contingent on the level of attendance, broadcast ratings, or other factors indicating public exposure (IRS, 1997b). All of these items are involved in the consideration of bowl game sponsorship agreements (Seifried \& King, 2012).

\section{UBIT Rule \#3: Substantially Unrelated Activity and Mission Statements}

Finally, the IRS believes if an organization conducts an activity with a profit motive and the activity is not substantially related to the organization's exempt purpose, the organization's activity likely engages in unfair competition. According to the Supreme Court in The United States v. American College of Physicians (1986), the existence of unfair competition in itself is not a prerequisite to impose UBIT but rather the mere likelihood of unfair competition is sufficient to issue the UBIT (Vari, 1992). Thus, if a reasonable and prudent person can perceive an element of unfair competition, a nonprofit/charitable organization can be sanctioned with the UBIT. To help further understand the possible analysis which might take place regarding this point, this review offers the Arizona Sports Foundation (ASF), organizers of the Fiesta Bowl, ideals in its mission statement as a lens. Those ideals include

1. Staging two of the top college football bowl games in the nation, and to assist the cause of higher education with the highest university payments possible

2. Having the people of Arizona host the most comprehensive pageant of community activities in the United States

3. To be Arizona's leading outlet for year-round sports and pageantry-related volunteer participation

4. To give companies and organizations unique opportunities for involvement in supporting our efforts

5. To be financially sound, and to contribute strongly and regularly to the state's economic development and to higher education nationwide

6. To be a source of national pride for all Arizonans (Department of the Treasury, 2010a).

Under the UBIT lens, the IRS would primarily focus upon each bowl game organization's ability to display economies of scope. Economies of scope are present if the activity is less costly when undertaken under the direction of the organization's exempt purpose (Vari, 1992). Based on the examples stated earlier, the economies of scope appear to be violated by the Fiesta Bowl and its BCS peers through excessive executive salaries, overly generous corporate perks, lobbying, and unnecessary spending on bowl game entertainment. In particular, it appears difficult to provide a rationale for the high executive salaries and unnecessary expenditures as a reasonable and prudent person could identify an existence of an unfair advantage for executives of bowl games that are not based on their market value as managers within a special and unique environment. Further, those activities and roles could be filled by other highly-qualified and capable individuals for less money. 


\section{Summary of 3 UBIT Rules Analysis}

Overall, this three-point UBIT analysis demonstrates bowl organizations appear to be subject to the UBIT because a reasonable and prudent individual can infer bowl committees operate a business considered as a trade or business. Next, the business of creating and managing a bowl game occurs on a regular basis through promotion, scheduling, lobbying, and advertising. Finally, the recent actions orchestrated and supported by bowl executives appear to be substantially unrelated to the organization's purpose because they create undue rewards. The resulting penalties from the IRS are to impose the UBIT and may include the suspension of tax-exempt benefits provided from $\$ 501(\mathrm{c})(3)$ without better attention to the mission.

To understand the ramifications of this outcome, we can review the aforementioned Arizona Sports Foundation. For the 2010 fiscal year, the Arizona Sports Foundation reported roughly $\$ 16.98$ million in revenue primarily from program services [i.e., game revenue and sponsorship agreements] (Department of the Treasury, 2010a). After accounting for operating expenses ( $\$ 13.8$ million) and salaries and other benefits ( $\$ 1.28$ million), the net income for the ASF for their FYE 2010 was $\$ 1.853$ million. Based on this review's findings, the IRS could apply the UBIT on the ASF's total net income or can use the fragmentation rule to tax specific income-producing activities potentially unrelated to the organization's mission.

As an example, the sponsorship revenue the ASF reported was $\$ 1.11$ million. After reducing this revenue by advertising and promotion expenses of $\$ 126,000$, sponsorship income is $\$ 984,000$ and is subject to taxation. Following the $\$ 1,000$ exemption for administrative convenience, the ASF unrelated taxable income would generate approximately $\$ 334,000$ in unrelated business income taxes. This would reduce the ASF's overall net income to $\$ 1.52$ million. Each fragmented activity could carry their own additional UBIT burden to reduce the net income. Should the IRS remove the ASF's overall tax exemption, the $\$ 1.853$ million total would be considered taxable income and at the $35 \%$ corporate income tax rate. Thus, $\$ 1.853$ million would create approximately $\$ 630,000$ in taxes, reducing the net profit to $\$ 1.223$ million.

\section{Conclusion}

The original purpose of bowl games was to generate business for the local economy as the host city desired for tourists to visit their particular locale (Seifried \& King, 2012; Zimbalist, 2009). However, as intercollegiate athletics evolved into a mature business throughout the 20th century, executive volunteers and philanthropists from the local community were replaced by full-time and part-time employees to operate a for-profit business throughout the sporting year (Seifried \& King, 2012). Some examples presented within this work discussed inflated salaries and improper corporate benefits; political lobbying; and increased game development expenses as examples of activities not in-line with the mission of bowl games. Further, these problematic behaviors should invite governmental interest to review current and future activity of these organizations and their ability to enjoy a $\$ 501(\mathrm{c})(3)$ tax exempt status.

Next, we would like to point out that aided by promotional efforts and highbudget marketing campaigns, a reasonable and prudent person can also conclude the BCS's new College Football Playoff is a commercial product created for consumption like all other bowl games. Additional evidence emerging from the BCS 
Presidential Oversight Committee suggested the championship game for their proposed playoff format will begin accepting bids from cities in the near future ("BCS Presidential Oversight Committee," 2012). There is little doubt as to why this new marketing strategy was created; significant television rating drops in recent years concerned bowl games and their college football partners (Seifried \& King, 2012). This information serves also serves as example that bowl committees are engaging in a trade or business conducted with a profit motive and that they no longer deserve $\$ 501(\mathrm{c})(3)$ tax exempt status without a change.

Again, organizations considered charitable in nature are exempt from any federal income taxation on any revenue generated by the company. Bowl organizations qualify for this exemption due to their claims that they provide educational and charitable benefits to the invited participants, the local community, and charitable partners. While this exemption is beneficial to bowl organizations, critics of these nonprofit businesses can claim an element of unfair rewards is in existence. Overall, this work supports the accusation that bowl games do not deserve their exempt status because they engage in activities which deviate from their core mission/purpose.

Next, this work recommends that if these committees wish to maintain their tax-exempt status, these organizations should monitor their expenditures and behaviors for all potential discrepancies unrelated to organization's educational mission and seek out opportunities to better meet the core values they established in their mission statements. Otherwise, bowl committees could have their tax exemption removed and thus, are subject to corporate taxes. Moreover, these organizations could lose funding from donations as individuals would be unable to claim an itemized deduction on their personal tax return due to the forfeiture of the $\$ 501$ (c) (3) status. With such a high penalty to pay for unrelated trades, bowl committees would be wise to closely monitor any activities that stray from the educational and charitable missions promoted.

Finally, to help realize bowl operations more closely to their educational and charitable missions, more bowl revenue should go toward potential partners. We recognize the decision to promote outside benefits may cause a loss of specialist personnel responsible for the recent commercial success of the college football postseason. However, we argue other specialists and experts willing to work and/or donate their time to help educational and charitable causes could emerge to help the creation and operation of bowl games. The number of volunteers is already very high for many bowl games and their associated activities. Thus, we anticipate the bowl game phenomenon could continue without it losing attractiveness as a mega-event or ability to produce quality payouts and benefits to partnering schools and charities.

\section{Notes}

${ }^{1}$ According to Seifried (2012) a horizontal agreement is an arrangement where competing organizations operating at the same level agree to cooperate for their collective benefit.

\section{References}

Appleby, A.D. (2010). For the love of the game: The justification for tax exemption in intercollegiate athletics. The John Marshall Law Review, 44(1), 179-207. 
Baratz, D. (2011, December 18). BCS football is mired in shady financial transactions. Retrieved from: http://wallstcheatsheet.com/stocks/bcs-football-is-mired-in-shadyfinancial-transactions.html/.

B.C.S. Media Guide. 2011-2012 (2011). Bowl Championship Series football. Retrieved from: http://espn.go.com/i/ncf/bcs/2011BCSGuide2.pdf

BCS Presidential Oversight Committee establishes new postseason format. (2012, June 26). Retrieved from http://www.bcsfootball.org/news/story?id=8099512.

Castillo, A. (2008, December 31). The Doobie Brothers to play the Orange Bowl Halftime Show, Thursday. Retrieved from: http://blogs.browardpalmbeach.com/countygrind/2008/12/ the_doobie_brothers_to_play_th.php

Charity Navigator. (2010). 2010 CEO Compensation Study. Retrieved from: http:// www. charitynavigator.org/_asset_/studies/2010_CEO_Compensation_Study_FinalRev. pdf.

College Bowls 2011-12. (2012, January 9). ESPN. Retrieved from: http://espn.go.com/ college- football/bowls.

Colombo, J.D. (2010). The NCAA, tax exemption, and college athletics. University of Illinois Law Review, 1, 109-163.

Community development. (2011). Orange Bowl. Retrieved from: http://www.orangebowl. org/ committee/community_involvement.aspx.

Craig, C.K., \& Weisman, K. (1994). Collegiate athletics and the Unrelated Business Income Tax. Journal of Sport Management, 8(1), 36-48.

Department of the Treasury. (2007). Orange Bowl Committee Inc. Tax Return (Form 990). Washington, D.C.: Internal Revenue Service Individual Forms and Publications Branch.

Department of the Treasury. (2008). United Way Tax Return (Form 990-T). Washington, D.C.: Internal Revenue Service Individual Forms and Publications Branch.

Department of the Treasury. (2009). Pasadena Tournament of Roses Association (Form 990). Washington, D.C.: Internal Revenue Service Individual Forms and Publications Branch.

Department of the Treasury. (2010a). Arizona Sports Foundation Tax Return (Form 990). Washington, D.C.: Internal Revenue Service Individual Forms and Publications Branch.

Department of the Treasury. (2010b). Sugar Bowl Tax Return (Form 990). Washington, D.C.: Internal Revenue Service Individual Forms and Publications Branch.

Department of the Treasury. (2010c). Orange Bowl Committee Inc. Tax Return (Form 990). Washington, D.C.: Internal Revenue Service Individual Forms and Publications Branch.

Guest Manual. (2010). Paper presented at Orange Bowl Summer Splash, Miami, FL. Retrieved from: http://www.azcentral.com/ic/news/bcs/images/summer-splash-agenda. pdf.

Harris, C. (2011, September 29). Bowl Championship Series executives'salaries stand out. Retrieved from: http://www.azcentral.com/news/articles/2011/09/29/20110929bcsexecutive-salary-questions.html.

Hill, F.R., \& Mancino, D.M. (2009). Taxation of exempt organizations. Chicago, IL: Thomson Reuters.

Hlas, M. (2011, March 30). The Sugar and Orange Bowl people like to spread the money around themselves. Retrieved from: http://thegazette.com/2011/03/30/the-sugar-andorange- bowl-people-like-to-spread-the-money-around-themselves/.

Internal Revenue Service. (1960a). Internal Revenue Code (\$511(a)). Washington, D.C.: Author.

Internal Revenue Service. (1960b). Internal Revenue Code (\$511(b)). Washington, D.C.: Author.

Internal Revenue Service. (1996). Internal Revenue Code (\$4958). Washington, D.C.: Author. Internal Revenue Service. (1997a). Internal Revenue Code (\$513(i)(2)(A)). Washington, D.C.: Author.

Internal Revenue Service. (1997b). Internal Revenue Code (§513(i)(2)(B)(i)). Washington, D.C.: Author. 
Internal Revenue Service. (2000). Internal Revenue Code (\$512(a)(1)). Washington, D.C.: Author. Retrieved from http://www.law.cornell.edu/uscode/text/26/512.

Internal Revenue Service. (2006a). Internal Revenue Code (\$501(c)(3)). Washington, D.C.: Author. Retrieved from http://www.law.cornell.edu/uscode/text/26/501.

Internal Revenue Service. (2006b). Internal Revenue Code (\$513(c)). Washington, D.C.: Author. Retrieved from http://www.law.cornell.edu/uscode/text/26/513.

Internal Revenue Service. (2010). Internal Revenue Code (\$513(a)(1)). Washington, D.C.: Author. Retrieved from http://www.law.cornell.edu/uscode/text/26/513.

Jacobellis v. Ohio, 378 U.S. 184, 197 (1964).

Jensen, E.M. (1987). Taxation, the student athlete, and the professionalization of college athletics. Utah Law Review, 35(1), 35-58.

Kaplan, R. (1980). Intercollegiate athletics and the unrelated business income tax. Columbia Law Review, 80(7), 1430-1473. doi:10.2307/1122171

Madel, C.W., Manning, B.D., \& Poulos, S.A. (2011). Counsel to the special committee of the board of directors of the Fiesta Bowl. Minneapolis, MN: Robins, Kaplan, Miller \& Ciresi, LLP.

McMurphy, B. (2011, January 10). Bowls pay bowl officials big bucks. Retrieved from: http://www.sfgate.com/cgi-bin/article.cgi?f=/g/a/2011/01/10/fanhousebowlspaybowl official.DTL.

Murphy, A., \& McKnight, M. (2011, March 29). Fiesta Bowl probe results in Junker dismissal, casts pall over BCS. Retrieved from: http://sportsillustrated.cnn.com/2011/ football/ncaa/03/29/fiesta-bowl-junker/index.html.

National Collegiate Athletic Association. (2010). NCAA Division I men's basketball championship principles and procedures for establishing the bracket. Indianapolis, IN: Author. Retrieved from: http://www.ncaa.com/sites/default/files/files/BracketPrinProc10-5-10.pdf.

National Collegiate Athletic Association. (2011). 2011-2012 Postseason Football Handbook: Bylaws 17.9.5 and 18.7.1 Retrieved from: http://fs.ncaa.org/Docs/champ_handbooks/ football/2011/2011_Postseason_Football.pdf.

National Collegiate Athletic Association v. Commissioner of Internal Revenue. 914 F.2d 1417 (10th Cir. 1990).

N.C.A.A. Postseason Football Finances Report. (2011). Summary of Revenue and Expense by Conference and BCS Revenue Distribution. Retrieved from: http://www.ncaa. org/ wps/wcm/connect/public/NCAA/Championships_old/Postseason+Football/ Financial+Reporting.

Pena, J., \& Reid, A.L.T. (2001). A call for reform of the operational test for unrelated commercial activity in charities. New York University Law Review, 76(6), 1855-1897.

Plunkett, J.P., \& Christianson, H.N. (2004). The quest for cash: Exempt organizations, joint ventures, taxable subsidiaries, and unrelated business income. William Mitchell Law Review, 31(1), 1-54.

Rose Bowl Operating Company. (2009). Basic Financial Statements: Year ended June 30, 2009. Retrieved from: http://ww2.cityofpasadena.net/councilagendas/2010\%20agendas/ Jan_11_10/5B1\%20Attachment\%20F.PDF.

Russo, R.D. (2013, April 24). BCS replaced by College Football Playoff. Huffington Post, Retrieved from: http://www.huffingtonpost.com/2013/04/24/bcs-college-footballplayoff-2014_n_3145643.html

Sansing, R.C. (2001). In search of profits: Measuring income from the unrelated commercial use of a tax-exempt organization's assets. Accounting Review, 76(2), 245-262. doi:10.2308/accr.2001.76.2.245

Seifried, C.S. (2012). The legality of the Bowl Championship Series (BCS): Examining procompetitive and anti-competitive outcomes on consumers and competitors. Journal of Legal Aspects of Sport, 21(2), 187-218. 
Seifried, C.S., \& King, B. (2012). Examining the history of Division I (FBS) bowl payouts: Current Bowl Championship Series (BCS) and non-BCS institutions and the growth of bowl games into BCS controlled contests. Sport History Review, 43(2), $206-228$.

Seifried, C.S., \& Smith, T. (2011). Congressional hearings and the Division I (Football Bowl Subdivision) postseason arrangement: A content analysis on letters, and testimonies. Journal of Issues in Intercollegiate Athletics, 4(1), 1-23.

Smith, B.T. (2010). The tax-exempt status of the NCAA: Has the IRS fumbled the ball? Sports Lawyers Journal, 17(1), 117-134.

Sugar Bowl. (2009). Audits of Financial Statements: June 30, 2009 and 2008. Retrieved from http://app1.lla.state.la.us/PublicReports.nsf/1E2C1235FB97038286257664005 1F281/\$FILE/00013A4A.pdf.

The United States v. American College of Physicians, 475 U.S. 834, 838-39 (1986).

Treasury Regulation § 1.513-1(c)(2)(i). (1983).

Trinidad v. Sagreda Orden de Predicadores. 263 U.S. 578. (1924).

Utah Code Ann. § 13-11 (2009).

Vari, F.J. (1992). The unrelated business income tax and its effects upon collegiate athletics. Akron Tax Journal, 9(1), 111-127.

Wetzel, D., Peter, J., \& Passan, J. (2010). Death to the BCS: The definitive case against the Bowl Championship Series. New York, NY: Penguin Group Inc.

Wight, B.R. (2012). College football's BCS (Bowl Charity System)?: An analysis of the characterization of BCS bowls as public charities that receive tax-exempt status. Sports Law Journal, 19(1), 129-144.

Williams, D.P., \& Seifried, C. (2013). Analyzing the prospects of the unrelated business income tax and $\$ 501(\mathrm{c})(3)$ on Division I athletic activities. The Journal of Sport, 2(1), 22-60.

Zimbalist, A. (2009). The BCS, antitrust, and public policy. Antitrust Bulletin, 54(4), 823-855. 